\author{
BOGUMIŁ NALEZIŃSKI \\ ORCID: 0000-0001-9777-3680 \\ Uniwersytet Pedagogiczny im. KEN w Krakowie
}

JUSTYNA HOLOCHER

ORCID: 0000-0002-4574-6848

Uniwersytet Pedagogiczny im. KEN w Krakowie

\title{
POLITYCZNOŚĆ KONTROLI KONSTYTUCYJNOŚCI AKTÓW NORMATYWNYCH W SYSTEMIE PRAWA POLSKIEGO - WYBRANE PROBLEMY
}

\begin{abstract}
Abstrakt: Pierwsza część rozważań poświęcona jest analizie pojęcia polityczności. Jej celem jest rozgraniczenie odmiennych znaczeń polityczności wraz z ich odniesieniem do działalności polskiego sądu konstytucyjnego w sferze kontroli konstytucyjności prawa. Część druga opracowania dotyczy czynników determinujących wkraczanie przez Trybunał Konstytucyjny w niedozwoloną dla tego organu sferę polityczności, a w konsekwencji upolitycznienie jego funkcjonowania. Czynniki te związane są zarówno z konstytucyjnymi wzorcami kontroli prawa, jak i jej przedmiotem. Autorzy podjęli też próbę wskazania elementów materialnych i proceduralnych działalności sądu konstytucyjnego, które mogą służyć ochronie apolityczności tego organu władzy sądowniczej.
\end{abstract}

Słowa kluczowe: polityczność nieuchronna, polityczność limitowana, polityczność partykularna, kontrola konstytucyjności, normy programowe, Trybunał Konstytucyjny

\section{WPROWADZENIE}

W niniejszym tekście podjęliśmy próbę uporządkowania dyskursu dotyczącego upolitycznienia działalności orzeczniczej Trybunału Konstytucyjnego (dalej: TK, Trybunał) oraz odpowiedzi na pytanie, czy możliwe jest uchronienie polskiego sądu konstytucyjnego przed niedopuszczalną na gruncie obowiązujących zasad ustrojowych, a przez to niebezpieczną systemowo, politycznością. Celem artykułu jest ustalenie, $w$ jakim stopniu akceptowalne w demokratycznym państwie jest zaangażowanie TK $\mathrm{w}$ prowadzenie polityki państwa $\mathrm{w}$ świetle konstytucyjnych zasad: podziału władzy (art. 10), niezależności i odrębności judykatywy (art. 173), jak również nadrzędności Konstytucji (art. 8). Innymi słowy interesuje nas usta- 
lenie przebiegu granicy między dozwoloną politycznością a niedopuszczalną polityzacją funkcjonowania TK.

Na wstępie czynimy dwa zastrzeżenia. Po pierwsze, rozważania mają charakter sprawozdawczo-postulatywny, a ich podstawą są wybrane przepisy Konstytucji oraz podstawowa (acz nie jedyna) funkcja TK, jaką jest kontrola konstytucyjności (legalności) prawa ${ }^{1}$. Poza przedmiotem analizy, mając jednak świadomość politycznego znaczenia pozycji ustrojowej TK, pozostawiamy też zagadnienie pozycji ustrojowej TK, w szczególności zaś trybu powoływania jego sędziów. Stanowi to odrębny, choć niewątpliwie niezmiernie istotny przedmiot badań ${ }^{2}$. Po drugie, nie wprowadzamy do nich ścisłej cezury (przed i po zmianach ustawowych dotyczących organizacji i funkcjonowania TK dokonanych w latach 2015-2017). Traktujemy bowiem analizowane problemy jako uniwersalne, nieustannie aktualne i wynikające z — determinowanej postanowieniami Konstytucji — roli ustrojowej sądu konstytucyjnego. Należy mieć jednak na uwadze, że niewątpliwie sytuacja polityczno-prawna może znacząco wpływać na skalę, zakres i intensywność omawianego tu zjawiska.

\section{PODSTAWOWE ZAŁOŻENIA DEFINICYJNE. POJĘCIE „POLITYCZNOŚCI”}

\section{1. „POLITYCZNOŚĆ” Z PERSPEKTYWY TEORII POLITYKI/FILOZOFII POLITYCZNEJ I FILOZOFII PRAWA}

Problematyka artykułu zasadniczo koncentruje się wokół rozumienia polityczności, uwzględniającego zaangażowanie Trybunału Konstytucyjnego w stosowanie (w szerokim znaczeniu) norm konstytucyjnych ${ }^{3}$, które do tego właśnie pojęcia w sposób bezpośredni (expressis verbis) lub choćby pośrednio się odwołują. Nie sposób jednak uprzednio nie odnieść się pokrótce do pewnych podstawowych znaczeń i kontekstów, w których pojęcie to występuje w myśli politycznej. Jej przedmiotem są przede wszystkim takie zagadnienia, jak: esencja polityczności

${ }^{1}$ Odmienne uwarunkowania mogą w omawianym tu kontekście towarzyszyć wykonywaniu przez sąd konstytucyjny funkcji kontroli konstytucyjności celów i działalności partii politycznych (art. 188 pkt 4 Konstytucji) czy też rozstrzygania sporów kompetencyjnych między centralnymi konstytucyjnymi organami państwa (art. 189 Konstytucji).

2 Jest to widoczne zwłaszcza w polskich realiach ustrojowych, wszak kontrowersje związane z tym problemem były jedną z głównych przyczyn trwającego kryzysu konstytucyjnego wokół TK; zob. P. Radziewicz, P. Tuleja, Konstytucyjny spór o granice zmian organizacji i zasad działania Trybunału Konstytucyjnego; czerwiec 2015-marzec 2016, Warszawa 2017.

3 Mówiąc o szerokim znaczeniu stosowania norm konstytucyjnych przez TK, mamy na myśli nie tylko opieranie na ich treści podstawy rozstrzygnięcia (w rozumieniu przyjętym w teoretycznym modelu sądowego stosowania prawa), lecz także uwzględnianie ich jako elementu (podstawy kontroli) wykonywanej przez TK funkcji kontroli prawa. 
(konflikt, przemoc, autorytet, najogólniej - kwestia ontologii, tego, co politycz$\mathrm{ne}^{4}$ ), granice pojęcia polityki (granice pomiędzy obszarami polityczności i niepolityczności, definiowanie zjawisk: quasi-politycznych, okołopolitycznych i politycznych, kryteriów i granic polityczności) oraz zagadnienia charakteru tych teorii (normatywna czy empiryczna teoria polityki) .

Pojęcie polityczności nie ma ustabilizowanego znaczenia, może też być ujmowane w różnych aspektach. Najczęściej definiowane jest jako sfera ludzkiej aktywności związana z funkcjonowaniem państwa. Większość teorii sytuuje przestrzeń polityczną w sferze publicznej ${ }^{6}$. Etymologia dotycząca tego, co polityczne, odnosi się do spraw związanych z polis. Termin ,polityczne” oznaczał dobre rządzenie sprawami publicznymi, działanie rozumnych elit i obywateli na rzecz społeczności ${ }^{7}$. Współcześnie pojęcie „polityczność” zostało po raz pierwszy teoretycznie opracowane w latach trzydziestych XX wieku przez C. Schmitta, który zaproponował dychotomiczną, bipolarną definicję polityczności, sprowadzając ją do rozróżnienia na przyjaciela i wroga we wszelkich ludzkich motywach i działaniach ${ }^{8}$. W jego teorii polityczność to wyraźne rozpoznanie sytuacji wobec możliwego konfliktu.

Każde przeciwieństwo religijne, moralne przekształca się ostatecznie w przeciwieństwo polityczne, o ile jest na tyle silne, by faktycznie podzielić ludzi na przyjaciół i wrogów. Polityczność czerpie siłę z różnych obszarów życia, sama nie ma określonego obszaru. Oznacza jedynie stopień intensywności rozproszenia lub zespolenia9.

Zdaniem tego autora polityczność istnieje tak długo, jak długo w ludzkim życiu pojawiają się duchowe sprzeczności, które nie tylko poruszają nasze emocje, lecz także zmuszają nas do podejmowania wyborów i działania w obronie określonego zespołu wartości. Polityczność zakłada więc nieustanny spór czy bardziej precyzyjnie — nigdy nieustającą gotowość do sporu ${ }^{10}$.

Polityczność jako sferę konfliktów, antagonizmów oraz walki o hegemonię postrzegają również E. Laclau i Ch. Mouffe ${ }^{11}$. Według nich porządek społeczny skazany jest na nieustanny i niemożliwy do wyeliminowania antagonizm. Walka, antagonizm i wykluczanie wpisane są w każdą formę społeczeństwa i jako takie

${ }^{4}$ Polityka/polityczność. Granice dyskursu, red. B. Krzysztan, W. Ufel, M. Zieliński, Wrocław 2016, s. 8 .

5 A. Czajowski, Polityczność działań społecznych, [w:] Polityka i polityczność. Problemy teoretyczne i metodologiczne, red. A. Czajowski, L. Sobkowiak, Wrocław 2012, s. 41.

6 Ibidem, s. 36.

7 A. Jabłoński, Polityka. Teoretyczna ewolucja pojęcia, [w:] Polityka i polityczność..., s. 11. Wedle Arystotelesa polityka to działanie na rzecz dobra wspólnego. Należy ją rozumieć jako uczestnictwo obywateli w rządzeniu w celu urzeczywistnienia sprawiedliwszego państwa i osiągnięcia wyższej formy ustrojowej; zob. Arystoteles, Polityka, przeł. L. Piotrowicz, Warszawa 2002.

8 C. Schmitt, Teologia polityczna i inne pisma, przeł. M.A. Cichocki, Kraków 2000, s. 198.

9 Ibidem, s. 209.

10 Ibidem, s. 26-27.

11 K. Morawski, Laclaua i Mouffe teoria polityczności, [w:] Polityka i polityczność..., s. 182; Polityka/polityczność..., s. 197-198. 
stanowią istotę tego, co polityczne. Z kolei M. Weber politykę postrzegał jako proces zdobywania i utrzymywania władzy, nieuchronnie związany z istnieniem państwa, podczas gdy R. Dahl uznawał ją za wywieranie wpływu, polityczność zaś jako fenomen przejawiający się obecnością stosunków wpływu rozumianych jako zespół działań zmierzających do zmiany zachowań jednych osób w interesie innych $^{12}$. Natomiast funkcjonalistyczna teoria T. Parsonsa za podstawę wyróżnienia sfery politycznej uznaje wynikającą z natury życia społecznego konieczność zapewnienia koordynacji działań zbiorowych.

Już wyłącznie hasłowe przedstawienie najbardziej popularnych w literaturze politologicznej określeń polityczności wskazuje na wielość możliwych odpowiedzi na pytanie, czym ona jest i jakie, pozytywne czy negatywne, znaczenie można jej przypisać. Przesądzenie tej kwestii wydaje się konsekwencją odmiennych wizji natury ludzkiej, które przekładają się na odmienne wizje polityczności ${ }^{13}$.

Zawężając pole rozważań do sfery prawa, trzeba zauważyć, że wiele problemów związanych z interpretacją pojęcia ,polityczności” zidentyfikowanych w teorii polityki pozostaje aktualna na gruncie teorii i filozofii prawa oraz dogmatyki prawniczej. Dzieje się tak między innymi dlatego, że prawnicy funkcjonują w dość wąskich wobec rzeczywistości społecznej ramach: legalne-nielegalne ${ }^{14}$. Kategorie te nie pozwalają na zrozumienie i rozładowanie w pełni powstających konfliktów społecznych ${ }^{15}$. Ponadto wciąż aktualne pozostają pytania, czy spory dotyczące kwestii politycznych mogą być w ogóle rozstrzygane prawem i czy normy prawne są zdolne do rozwiązywania problemów życia politycznego wynikających z odmiennych zapatrywań członków społeczeństwa i grup społecznych.

Bez wątpienia polityczność jest częścią myślenia o prawie i to niezależnie od tego, czy przyjmuje się pogląd o autonomiczności kultur i porządków prawnych wobec polityki, czy pogląd przeciwny. Związki prawa z polityką są częścią rzeczywistości prawnej, mają charakter faktyczny, a niekiedy także postulatywny. Dotyczą zarówno płaszczyzny stanowienia, jak i stosowania prawa. Zwykle wskazuje się kilka podstawowych kontekstów, w których polityczność jest przywoływana i w których ma znaczenie:

1. prawo powstaje w procesie politycznym,

2. prawo reguluje kwestie polityczne,

3. prawo jest instrumentem uprawiania polityki ${ }^{16}$.

12 Zob. R.A. Dahl, Modern Political Analysis, Prentice Hall 1991.

13 L. Błaszczykiewicz, Polityczność w teoriach socjologicznych Parsonsa, Giddensa i Bourdieu, [w:] Polityka i polityczność..., s. 179.

14 F. Rakoczy, Autonomia prawa a problem jego polityczności, [w:] Polityka/polityczność..., s. 212-213.

15 Ibidem, s. 224.

16 J. Zajadło, Prawoznawstwo - polityczność nauki czy nauka polityczności?, [w:] Polityczność nauki prawa i praktyki prawniczej, red. A. Bator, P. Kaczmarek, „Przegląd Prawa i Administracji” 110, 2017, s. 42. 
Pierwsza okoliczność wydaje się najmniej sporna i kontrowersyjna. Dotyczy ona zagadnień o charakterze proceduralnym i instytucjonalnym. Związana jest z demokratycznymi regułami powoływania organów prawodawczych oraz procedurami stanowienia prawa.

Druga odnosi się do treści prawa, rodzaju i zakresu regulowanych stosunków społecznych, a zatem esencji polityczności oraz granic między obszarami polityczności i niepolityczności. Próba wyjaśnienia tych kwestii napotyka już na wstępie zasadniczą trudność wynikającą z niejasności pojęcia „polityczności”, uniemożliwiającą w konsekwencji przypisanie tej cechy konkretnemu sporowi, konfliktowi czy sprawie (cywilnej, karnej, administracyjnej). „Polityczność” w wymiarze prawnym pozostaje $\mathrm{w}$ związku $\mathrm{z}$ tym tak samo niejasna i wieloznaczna jak $\mathrm{w}$ teorii polityki i filozofii politycznej. Nie wiemy, czy jest cechą immanentną pojęć i instytucji prawnych, czy raczej cechą przygodną i relatywną, nabytą, nadaną? Niewyjaśniona pozostaje także jej relacja do wymogu legalności jako granicy dopuszczalności i ważności działań podjętych w sferze prawa. Ponadto w treści aktów prawnych pojawiają się równie niejasne pojęcia „apolityczności”"17 czy „,neutralności politycznej”"18. Odwołują się one wprawdzie do wspólnego pojęcia polityczności, natomiast kontekst ich przywołania oraz funkcja są inne niż w przypadku omawianej tu kwestii polityczności wzorców kontroli konstytucyjności aktów prawnych.

Trzecia okoliczność, kiedy prawo jest postrzegane jako instrument uprawiania polityki, wydaje się najbardziej kontrowersyjna. Dotyka aksjologicznego aspektu stanowienia oraz stosowania prawa i sprowadza się do odpowiedzi na pytanie, czemu prawo powinno służyć i kto oraz w jaki sposób powinien o tym decydować czy to kontrolować. Dotyczy to działań zarówno ściśle politycznych, jak i mających kontekst polityczny. Te pierwsze są podejmowane ze świadomością takich skutków, a drugie wywołują skutki polityczne w sposób niezamierzony i przypadkowy. Część tych ostatnich, za K. Opałkiem, zaczęto nazywać działaniami o doniosłości politycznej ${ }^{19}$.

Polityka i polityczność są obecne na poziomie ontologicznym prawa, nie sposób zatem ich wyeliminować ${ }^{20}$. Można natomiast podjąć próbę wyznaczenia granic traktowania prawa jako jednego z instrumentów uprawiania polityki. Dotyczy to władzy ustawodawczej, wykonawczej, a w szczególności sądowniczej (w tym trybunalskiej), której poświęcony jest niniejszy tekst. W działalności legislacyjnej polityka jest powszechnie uznawana za celową działalność prawodawcy, a prawo będące efektem tych działań jest traktowane jako urzeczywistniona polityka. W działalności orzeczniczej uznawanie norm prawnych za instrument realizacji określonych celów politycznych sprowadza się do wydawania rozstrzy-

17 Zob. np. art. 1 ust. 2 ustawy z dnia 9 kwietnia 2010 roku o Służbie Więziennej (Dz.U. z 2019 r. poz. 1427, ze zm.).

18 Zob. np. art. 153 ust. 1 Konstytucji.

19 K. Opałek, Zagadnienia teorii prawa i teorii polityki, Warszawa 1986.

20 F. Rakoczy, op. cit., s. 219. 
gnięć w konkretnych sprawach, które to rozstrzygnięcia urzeczywistniają założenia o charakterze politycznym. Zwykle w takich sytuacjach wykorzystuje się dyrektywy wykładni funkcjonalnej ${ }^{21}$. Przyjmuje się, że kontekst funkcjonalny ma charakter kontekstu sytuacji społeczno-politycznej, w której norma obowiązuje i jest stosowana. Dyrektywy wykładni funkcjonalnej budowane są właśnie w odniesieniu do trzech elementów prawa: jego funkcji, celu oraz ocen moralnych ${ }^{22}$, które nadają treść polityczności.

Zasadnicze obawy związane $\mathrm{z}$ dopuszczalnością orzekania w sprawach politycznie uwikłanych oraz akceptacją racji i argumentów politycznych dotyczą problemu upolitycznienia i instrumentalizacji prawa. To pierwsze definiowane jest najczęściej jako przesunięcie wyznaczonych granic między polityką a prawem $^{23}$. Natomiast instrumentalizacja jest kwalifikowanym upolitycznieniem prawa. Prawo, jak pisze S. Wronkowska, ma zdolność do bycia środkiem osiągania określonych stanów rzeczy, do realizacji pewnych celów, może zatem służyć instrumentalizacji. Polityczna instrumentalizacja prawa to dokonywanie działań $\mathrm{w}$ imię wartości nieakceptowanych w systemie prawa ${ }^{24}$. Istnieją jednak konieczne związki prawa z polityką, które nie muszą oznaczać jednoczesnej partykularnej instrumentalizacji ${ }^{25}$. Ponadto $\mathrm{w}$ systemie prawnym przewidziane są ograniczenia instytucjonalne polityczności, określające konsekwencje naruszenia przyjętych standardów. Mimo to może jednak dochodzić do maskowania polityczności zapadających decyzji za pomocą autorytetu prawa i rozumowań prawniczych ${ }^{26}$.

Podsumowując, należy wskazać, że wyróżnione konteksty pozostają z sobą $\mathrm{W}$ związku. Z perspektywy uwzględnianego $\mathrm{w}$ analizie sądu konstytucyjnego pierwszy z nich ma znaczenie przy kontroli określonych procedur stanowienia prawa. Drugi odnosi się do merytorycznych, treściowych zagadnień rozpoznawanych przez TK. Natomiast w kontekście ustrojowego statusu TK, jego działalności orzeczniczej i konsekwencji rozstrzygnięć szczególnie istotny jest trzeci z nich. Wyznacza bowiem pewne standardy podejścia do prawa oraz granice jego instrumentalnego wykorzystania.

\section{PRÓBA SYSTEMATYZACJI POJĘĆ}

Mając na uwadze, że pojęcia polityki i polityczności w teorii polityki oraz filozofii politycznej nie mają ustabilizowanego jednego i dominującego znaczenia, podjęliśmy próbę ich ,prawniczego” usystematyzowania. Zadanie to utrudnia

21 Ibidem, s. 220, 221.

22 M. Kordela, Aksjologiczna wykładnia prawa, [w:] Polityczność nauki prawa..., s. 150.

23 T. Biernat, Między polityka a prawem. Problem ,upolitycznienia” tworzenia prawa, [w:] Polityczność nauki prawa..., s. 115.

${ }^{24}$ S. Wronkowska, Kilka tez o instrumentalizacji prawa i ochronie przed nia, [w:] Polityczność nauki prawa..., s. 107, 110.

25 J. Zajadło, op. cit., s. 43-44.

${ }^{26}$ F. Rakoczy, op. cit., s. 215. 
fakt, że TK nie odwołuje się do żadnej z koncepcji polityczności, nie formułuje również jej własnej definicji. Nasze propozycje są wynikiem poszukiwań takich ujęć, które byłyby najbardziej adekwatne do pozycji ustrojowej i specyfiki orzecznictwa TK. Przyjmujemy trzy rozumienia polityczności.

Pierwsza z wyróżnionych polityczności to polityczność „nieuchronna”. To najszersza z proponowanych interpretacji tego pojęcia. Większość teorii statuuje przestrzeń polityczną $w$ sferze publicznej ${ }^{27}$. Nawiązuje ona do polityki rozumianej jako działalność państwa (władz publicznych). W tym sensie wszelkie działania organów władzy, a nawet obywateli (na przykład media, zgromadzenia) także są elementami polityki i mają polityczny walor. W takim rozumieniu polityczność jest nierozerwalnie związana $\mathrm{z}$ istnieniem państwa ${ }^{28}$, z działalnością instytucji państwowych oraz publicznych ${ }^{29}$. Istnieje, mimo że jej treść się zmienia ${ }^{30}$. W tym kontekście oczekiwanie od TK (szerzej — organów „trzeciej władzy”) a p oli ty c zno ści jest czymś irracjonalnym, ponieważ trudno mówić o apolityczności działań organu władzy publicznej. Polityczność w tym znaczeniu nie zna swego zaprzeczenia, nie podlega wartościowaniu. Po prostu jest obecna, tworząc ogólny klimat stanowienia i stosowania prawa.

Druga polityczność została określona mianem „limitowanej”. Jest wyznaczana pozycją ustrojową i kompetencjami danego organu. Do tego rozumienia polityczności nawiązuje prawodawca w wielu normach Konstytucji, przypisując poszczególnym organom kompetencje do prowadzenia ,polityki” (na przykład art. 146) czy nakazując „,kierunkowe” jej prowadzenie (normy programowe, optymalizacyjne). Najmniej limitowana (najszersza) jest ona w wypadku organów zaliczanych do „władz politycznych”, a więc legislatywy i egzekutywy. Wycinkowo może być jednak realizowana także przez organy władzy sądowniczej - sądy i trybunały, w szczególności w tych przypadkach, w których organy judykatywy mają stosować unormowania Konstytucji i ustaw odwołujących się do komponentów politycznych (w znaczeniu prowadzenia pewnej polityki). Przykładem realizacji takiej właśnie polityczności, ograniczonej wprawdzie ramami, które uniemożliwiają TK wkraczanie w sferę innych władz, jest jego działalność jako kontrolera zgodności ustawodawstwa z Konstytucją (w tym z jej normami programowymi). Jest ona również obecna w orzecznictwie sądów powszechnych i administracyjnych stosujących ustawowe dyrektywy orzekania (na przykład wymiaru kary) ${ }^{31}$, realizujące w ten sposób określone polityki sądowe. Są one przykładami koniecznych związków prawa z polityką, które nie muszą jeszcze oznaczać jego instrumentalizacji ${ }^{32}$.

27 A. Czajowski, op. cit., s. 36.

${ }_{28}$ M. Weber, Gospodarka i społeczeństwo. Zarys socjologii rozumiejącej, Warszawa 2002.

29 A. Jabłoński, op. cit., s. 14.

30 L. Błaszczykiewicz, op. cit., s. 176-177.

31 Przykładowo art. 53 k.k.; art. 150 ust. 4 ustawy z dnia 1 marca 2018 roku o przeciwdziałaniu praniu pieniędzy oraz finansowaniu terroryzmu (Dz.U. z 2018 r. poz. 723).

32 J. Zajadło, op. cit., s. 41. 
I wreszcie trzeci rodzaj polityczności - tak zwana polityczność partykularna („niedozwolona”). W tym ujęciu ewentualna aktywność organów władzy sądowniczej w tak rozumianej sferze oznaczałaby w konsekwencji, że sądy i TK funkcjonują jako wykonawcy określonego (także własnego) programu politycznego. Partycypację organów „trzeciej władzy” w polityczności partykularnej należy uznać za naruszenie zasad porządku prawnego, stąd postulaty, aby w tym znaczeniu organy były właśnie „apolityczne”. Trzecie z proponowanych tu ujęć można wiązać z pojęciem upolitycznienia rozumianym jako naruszenie wyznaczonych granic między polityką a prawem. W tym kontekście polityczność będzie kwalifikowana jako subiektywne, przygodne, partykularne zaangażowanie w spór polityczny, a nie obiektywne i konieczne wypełnienie pewnego fenomenu treścią polityczną ${ }^{33}$. Polityczność ta może dotyczyć rozmaitych spraw, a także mieć różny stopień i intensywność.

\section{POLITYCZNOŚĆ W DZIAŁALNOŚCI ORZECZNICZEJ TK}

Zacieranie się granic pomiędzy przedstawionymi ujęciami polityczności jest faktem o znaczeniu normatywnym. Zagrożenia z nim związane są widoczne zwłaszcza w wypadku relacji zachodzącej między politycznością limitowaną a politycznością niedozwoloną. Od zagrożeń tych nie jest również wolna działalność sądu konstytucyjnego, w szczególności w ramach realizowanej przez ten organ funkcji kontroli konstytucyjności i legalności prawa (art. 188 pkt 1-3 i 5, art. 193 $i$ art. 79 Konstytucji ${ }^{34}$ ). Polityczne uwarunkowanie towarzyszące realizowaniu tej funkcji można zaobserwować w ramach każdego z elementów wyznaczających zarówno podstawę, jak i przedmiot kontroli prawa wykonywanej przez TK. Doświadczenia płynące z praktyki funkcjonowania polskiego sądu konstytucyjnego w ostatnich kilku latach dowodzą, że problem jej politycznego zdeterminowania może być również rozważany na płaszczyźnie proceduralnej ${ }^{35}$, co jednak pozostawiamy poza ramami niniejszej analizy.

\section{POLITYCZNOŚĆ PODSTAWY (WZORCÓW) KONTROLI PRAWA}

Naturalną przyczyną problemów z przekraczaniem granic omawianych tu ujęć polityczności jest niewątpliwie sama specyfika norm konstytucyjnych, które

33 Ibidem, s. 43-44.

34 Wskazane przepisy mogą być zarazem uznane za konstytucyjne zakotwiczenie trzech trybów kontroli prawa realizowanej przez polski TK, to jest kontroli abstrakcyjnej (wnioski), kontroli konkretnej (pytania prawne) oraz kontroli inicjowanej skargami konstytucyjnymi.

35 Tytułem przykładu można wskazać kwestie sposobu wyznaczania składów orzekających czy też różnicowania szybkości prowadzonych postępowań oraz ich finalizowania merytorycznymi rozstrzygnięciami (praktyka umarzania postępowań w sprawach konstytucyjności ustaw z odwołaniem się do konsekwencji zasady dyskontynuacji prac parlamentarnych). 
są podstawowym wzorcem kontroli prawa wykonywanej przez sąd konstytucyjny. Specyfika ta wiąże się z ogólnością ich treści, niedookreśleniem wyrażonego w nich zakresu normowania, jak również ze szczególnymi mechanizmami dokonywania ich wykładni ${ }^{36}$. W dalszych rozważaniach pragniemy skoncentrować się na kilku wybranych kwestiach wynikających z odwołania się do unormowań Konstytucji jako podstawy kontroli.

W ocenie wielu autorów dobrym przykładem na niebezpieczeństwo wkroczenia przez TK w sferę niepożądanej polityczności może być dokonywana w procesie kontroli prawa interpretacja konstytucyjnych norm programowych (na przykład art. $65,71,74,75,76$ Konstytucji) wraz z towarzyszącymi jej mechanizmami ważenia ${ }^{37}$. Należy przy tym zauważyć, że normy programowe nie zawsze są uznawane przez TK za dozwolony wzorzec kontroli konstytucyjności kwestionowanych aktów prawnych ${ }^{38}$.

Bliższe wyjaśnienie tego problemu wymaga kilku uwag wprowadzających dotyczących przedmiotu ,interpretacji ważeniowej” dokonywanej w procesie stosowania norm programowych. Normy te wykazują bowiem daleko idącą specyfikę ${ }^{39}$. Z punktu widzenia swojej struktury normy programowe mają charakter zasad, a nie reguł, mogą być więc spełnione w różnym stopniu, w zależności od konkretnej sytuacji kolizyjnej ${ }^{40}$. Nie określają one dokładnie swego zakresu zastosowania i zakresu normowania, nie wskazują też jednoznacznie, jak konkretnie należy się

${ }^{36}$ Zob. np. P. Tuleja, Stosowanie Konstytucji RP w świetle zasady jej nadrzędności (wybrane problemy), Kraków 2003. Jako przykład można również wskazać kontrowersje towarzyszące przyjmowanemu w orzecznictwie TK sposobowi wykładni ogólnych zasad ustrojowych, na czele z klauzulą demokratycznego państwa prawnego wyrażoną w art. 2 Konstytucji; zob. L. Morawski, Spór o pojęcie państwa prawnego, „Państwo i Prawo” 1994, nr 4, s. 3-12.

37 T. Gizbert-Studnicki, A. Grabowski, Normy programowe w Konstytucji, [w:] Charakter i struktura norm konstytucji, red. J. Trzciński, Warszawa 1997, s. 126-127; zob. też R. Alexy, Theorie der Grundrechte, Baden-Baden 1985; M. Araszkiewicz, T. Gizbert-Studnicki, Teoria praw podstawowych Roberta Alexy'ego, „Przegląd Sejmowy” 2011, nr 3, s. 113-129; M. Florczak-Wątor, Ważenie zasad konstytucyjnych jako podstawa sadowej wyktadni prawa, [w:] Argumentacja konstytucyjna w orzecznictwie sadowym, red. A. Kotowski, E. Maniewska, Warszawa 2016, s. 24-38.

$38 \mathrm{~W}$ orzecznictwie TK brakuje jednolitego stanowiska odnośnie do dopuszczalności konstruowania wzorca kontroli kwestionowanych przepisów, opierając się na samodzielnie ujmowanych normach programowych, wyklucza się jednak taki zabieg w wypadku postępowania inicjowanego skargą konstytucyjną; zob. np. P. Mikłaszewicz, Objaśnienie do art. 75, [w:] Konstytucja RP. Komentarz, t. 1, red. M. Safjan, L. Bosek, Warszawa 2016, s. 1713.

39 Zastrzegamy przy tym, że bezpośrednio za T. Gizbertem-Studnickim i A. Grabowskim, a pośrednio za szkołą poznańską, w dalszych rozważaniach przyjęte zostało odróżnienie przepisu prawnego i normy prawnej, zakładające, że przepis prawny to ograniczony redakcyjnie fragment tekstu prawnego, a norma prawna to norma postępowania obowiązująca w systemie prawa, wyznaczająca wzorzec powinnego zachowania. Udzielenie zaś odpowiedzi na pytanie, kto w jakich okolicznościach jak powinien się zachować, będące interpretacją prawa, polega na rekonstrukcji norm zakodowanych w przepisach prawnych; zob. eidem, op. cit., s. 127.

40 Ibidem, s. 131. 
zachować. Ich bezpośrednim adresatem są „,władze publiczne”41, w treści zaś przepisów określających ich zakres normowania ustrojodawca z reguły odwołuje się do pojęcia ,polityki” jako sfery, w jakiej winny one znaleźć zastosowanie. Wysławiają normy nakazujące organom władzy publicznej podjęcie działań zmierzających do realizacji określonego celu (są nakazami optymalizacyjnymi), nie wyznaczając bezpośrednio żadnego zachowania swym adresatom jako nakazanego bądź zakazanego. Spośród katalogu możliwych zachowań pozostawiają wybór środków ${ }^{42}$.

Udzielenie odpowiedzi na pytanie, jakiego rodzaju zachowań normy te nakazują lub zakazują, wymaga odwołania się przez podmiot stosujący prawo do wiedzy empirycznej, a w szczególności do wiedzy o związkach kauzalnych między pewnymi zachowaniami a realizacją stanów rzeczy wskazanych jako cele ${ }^{43}$. Jak wskazują T. Gizbert-Studnicki i A. Grabowski, jest to problematyczne z uwagi na naturę rzeczywistości społecznej i stan nauk społecznych oraz w związku ze sposobem określania celów przez przepisy będące podstawą norm programowych, które zwykle formułowane są z zastosowaniem wyrażeń wartościujących. Cele te często nie są określane jako finalne stany rzeczy, lecz jako pewne tendencje czy idee regulatywne, które nigdy nie mogą być spełnione w pełni ${ }^{44}$. Dlatego trudno wskazać wystarczająco precyzyjne intersubiektywne kryteria pozwalające na jednoznaczne i bezsporne stwierdzenie, jakie zachowania są nakazane lub zakazane przez normy programowe oraz czy i w jakim stopniu taki cel został spełniony ${ }^{45}$. W konsekwencji niezrealizowanie celu wskazanego przez odpowiedni przepis Konstytucji nie może w każdym przypadku przesądzać o tym, że odpowiednia norma programowa została naruszona ${ }^{46}$.

Normy programowe nakładają na swoich adresatów obowiązki, które nie są definitywne, lecz mają charakter obowiązków prima facie, co wymaga ustalenia, czy podjęcie działania zmierzającego do realizacji celu wskazanego przez tę normę nie uniemożliwia lub nie utrudnia realizacji celów określonych przez inne normy programowe. Gdyby taka sytuacja zaistniała, należałoby „wyważyć” oba cele. Wiąże się to zawsze $\mathrm{z}$ ograniczeniem praw, co w państwie prawa wymaga uzasadnienia na podstawie zasady proporcjonalności ${ }^{47}$. W teorii i w praktyce wy-

${ }^{41} \mathrm{~W}$ doktrynie podkreśla się w związku z tym, że w kręgu adresatów norm programowych znajdują się wszystkie organy i instytucje, których właściwość obejmuje daną kwestię; zob. L. Garlicki, Artykut 76, [w] Konstytucja RP. Komentarz, red. L. Garlicki, t. 5, Warszawa 2007, s. 4; z kolei M. Florczak-Wątor wskazuje w tym zakresie na organy stanowiące i stosujące prawo, zob. Komentarz do art. 76, [w:] Konstytucja Rzeczypospolitej Polskiej. Komentarz, red. P. Tuleja, Warszawa 2019, s. 251.

42 T. Gizbert-Studnicki, A. Grabowski, op. cit., s. 134.

43 Ibidem, s. 129, 136.

44 Ibidem, s. 131.

45 Ibidem.

46 Ibidem, s. 138.

47 G. Maroń, Formuła ważenia zasad prawa jako mechanizm usuwania ich kolizji na przykładzie koncepcji Roberta Alexego, „Zeszyty Naukowe Uniwersytetu Rzeszowskiego. Seria Prawnicza” 53, 2009, s. 94. 
wołuje to liczne wątpliwości. Procedura ważenia/wyważania jest problematyczna głównie ze względu na zasadność i racjonalność wyboru kryteriów, wedle jakich ma być dokonywana, oraz wartość uzyskanego rezultatu. Podstawowy problem związany z ważeniowym sposobem usuwania kolizji, dotyczący zresztą nie tylko norm programowych, sprowadza się do pytania, czy opiera się on na prawnych, czy pozaprawnych kryteriach. Jest to o tyle istotne, że w drugim przypadku zostałaby wykluczana możliwość sądowej kontroli trafności takich rozstrzygnięćt8.

Mimo zarysowanych wątpliwości przyjmujemy, za T. Gizbertem-Studnickim i A. Grabowskim, że możliwe jest sformułowanie takich wymagań dla procedury „wyważania”, które mają charakter prawny, i w konsekwencji ustalenie, czy rozstrzygniecie jest prawnie wadliwe, czy nie. Wspomniani teoretycy prawa formułują cztery warunki „poprawności” wyważania:

1. cele pozostające w kolizji winny zostać w należyty sposób zidentyfikowane, a ponadto winny mieć charakter prawny, co oznacza, że powinny obowiązywać normy nakazujące realizację każdego z tych celów; nieprawidłowe będzie rozstrzygnięcie, które nie uwzględni któregoś z relewantnych celów, względnie uwzględni taki cel, który nie ma charakteru prawnego;

2. zastosowanie środków prowadzących do realizacji jednego z kolidujących celów nie powinno prowadzić do utrudnienia realizacji innych celów w stopniu większym niż niezbędny do realizacji pierwszego z nich (zasada proporcjonalności);

3. im wyższy stopień naruszenia jednego z kolidujących celów, tym ważniejsza musi być realizacja drugiego z nich (zasada sprawiedliwości);

4. jeżeli rozstrzygnięcie kolizji celów polega na odwołaniu się do zachodzącej pomiędzy nimi in abstracto relacji hierarchicznej, to relacja ta winna zostać prawidłowo ustalona, opierając się na kryteriach prawnych ${ }^{49}$.

Szeroko określony adresat (,władze publiczne”) przepisów Konstytucji wyrażających normy programowe obejmuje swoim zakresem także sąd konstytucyjny. Tym samym włącza TK w sferę limitowanej polityczności, choć oczywiście w znacząco innym kontekście i w związku z wykonywaniem jakościowo odmiennych kompetencji w porównaniu do organów władz politycznych — legislatywy i egzekutywy. Sąd konstytucyjny staje się jednak również organem stosującym normy programowe w tym sensie, że mogą one funkcjonować jako kryteria kontroli konstytucyjności ustaw. Także zdaniem T. Gizberta-Studnickiego i A. Grabowskiego niedefinitywne formułowanie obowiązków przez normy programowe nie wyklucza a limine pełnienia przez nie funkcji takiego kryterium. Należy mieć jednak świadomość, że nie zawsze i nie każda $\mathrm{z}$ norm programowych $\mathrm{z}$ osobna może być podstawą uznania za niekonstytucyjną ustawy nierealizującej celu wskazanego przez normę programową lub że jakakolwiek norma programowa z osobna może stanowić podstawę

48 T. Gizbert-Studnicki, A. Grabowski, op. cit., s. 141-142.

49 Ibidem, s. 138. 
„pozytywnych” roszczeń obywateli wobec państwa ${ }^{50}$. Ponadto nie zawsze zastosowanie tej procedury pozwala na wskazanie jednego prawidłowego rozstrzygnięcia. Krytycy ważenia twierdzą, że implementacja tej procedury pozwala często uznać za racjonalne dwa czy nawet więcej rozstrzygnięć: „formuła ważenia nie tyle że nie determinuje jednego rozwiązania, co w wielu przypadkach nie eliminuje żadnego z potencjalnych rozstrzygnięć" ${ }^{1}$. Taka konstatacja może podawać w wątpliwość jej konkluzywność, a więc użyteczność w stosowaniu prawa.

Opisane trudności odnośnie do interpretacji i stosowania norm programowych towarzyszą niewątpliwie również TK w procedurze kontroli zgodności prawa z wzorcami konstytucyjnymi, które do tychże norm się odwołują. Przeprowadzana przez sąd konstytucyjny ocena przyjętych przez ustawodawcę przesłanek wyboru określonej metody realizacji celów wskazanych w normach Konstytucji łatwo może jednak przekroczyć wyznaczone dla tego organu granice. Przedmiotem tej oceny pozostawać powinna bowiem zawsze wiedza, jaką dysponował twórca unormowań podlegających kontroli, nie zaś ,wiedza własna” TK, odszukiwana i ustalana samodzielnie przez sędziów konstytucyjnych, niezależnie i niejako w zastępstwie „racjonalnego prawodawcy”. Może to wywoływać dodatkowe trudności, w sytuacji gdy odtworzenie i weryfikacja tych przesłanek jest utrudniona czy wręcz niemożliwa (na przykład wskutek przyjętego przez ustawodawcę trybu i tempa procedowania nad uchwalaną ustawą). W naszej ocenie nawet wówczas TK nie jest jednak uprawniony do oparcia oceny konstytucyjności rozwiązań przyjętych w zakwestionowanych przepisach na samodzielnie i w zastępstwie prawodawcy ustalanej wiedzy „empirycznej”. Oznaczałoby to bowiem wkroczenie przez sąd konstytucyjny w sferę - niedozwolonej dla tego organu — polityczności partykularnej. Uwzględnianie takiej wiedzy „własnej” zaś nieuchronnie może prowadzić do przypisania TK motywów subiektywnych, czyli nadania jego orzecznictwu cech polityczności niedozwolonej, pozostającej w opozycji do innych obowiązujących zasad funkcjonowania państwa. Takie działanie TK byłoby narażone na zarzut traktowania przez sąd konstytucyjny postanowień ustawy zasadniczej jako narzędzia polityki ${ }^{52}$.

Jak już podkreślaliśmy, ryzyko zacierania się granic między dwiema politycznościami (limitowaną i partykularną) nie jest związane wyłącznie z konstytucyjnymi normami programowymi. Pojawia się ono również w przypadku stosowania innych norm konstytucyjnych, zwłaszcza — przywołanych wcześniej w kontekście opisywanej procedury ważenia — zasady proporcjonalności ograniczania

50 Ibidem, s. 141-142. Takie też stanowisko zajmuje polski sąd konstytucyjny w kontekście dopuszczalności potraktowania większości norm programowych za podstawę (wzorzec) kontroli przepisów kwestionowanych w trybie skargi konstytucyjnej; zob. np. wyrok TK z dnia 29 września 2003 roku, sygn. K 5/03, OTK ZU nr 7/2003, poz. 77.

51 G. Maroń, op. cit., s. 104.

52 A. Sulikowski, Konstytucjonalizm wobec ,zemsty postmodernizmu”, [w:] Polityczność nauki prawa..., s. 104. 
korzystania z konstytucyjnych wolności i praw (art. 31 ust. 3 Konstytucji). Ocena wystąpienia - stanowiącej kluczowy element tej zasady — przesłanki konieczności (w tym proporcjonalności sensu stricto) z reguły wymaga też odwołania się do pewnych kryteriów, wiedzy i ocen pozaprawnych ${ }^{53}$. Stawia to ponownie TK przed wyzwaniem poszukiwania rozstrzygnięcia, nie tyle opierając się na własnej, samodzielnie pozyskanej znajomości problemu, ile w związku z oceną wiedzy ustawodawcy, jaką dysponował on, ustanawiając kontrolowane unormowania ${ }^{54}$.

\section{POLITYCZNE UWARUNKOWANIA PRZEDMIOTU KONTROLI PRAWA}

Nieco inne zagrożenia, również jednak związane z przekroczeniem granic dopuszczalnej ustrojowo polityczności funkcjonowania TK, łączą się z przedmiotem kontroli wykonywanej przez ten organ. Sąd konstytucyjny w orzeczeniach podejmowanych w ramach funkcji kontroli prawa konsekwentnie odwołuje się do - wskazanego wcześniej — rozróżnienia przepisów prawa i norm prawnych, przyjmując, że rzeczywistym przedmiotem jego kontroli pozostają normy prawne dekodowane $\mathrm{z}$ treści zakwestionowanych przepisów. Tego rodzaju założenie wywołuje liczne następstwa, zarówno materialne, jak i proceduralne, które także mogą wykazywać ścisły związek z omawianą przez nas problematyką. Jedną z podstawowych jest specyfika konstruowania przez podmioty inicjujące postępowanie przed TK przedmiotu zaskarżenia w sposób, który można określić jako ,interpretacyjny”55. Proceduralnym następstwem takiego określenia przedmiotu kontroli jest konieczność wyrażenia rozstrzygnięcia przez TK dylematu (nie)zgodności kwestionowanych unormowań $w$ adekwatnej do przedmiotu zaskarżenia formie, to znaczy również wyroku interpretacyjnego ${ }^{56}$. Nie budzi większych zastrzeżeń sytuacja, w której inicjowana kontrola rzeczywiście ma za przedmiot wyłącznie problem konstytucyjności norm o charakterze generalno-abstrakcyjnym, prawidłowo wyinterpretowanych z przepisów kwestionowanego aktu prawnego. Problem powstaje jednak, gdy taki

53 Zob. też K. Wojtyczek, Granice ingerencji ustawodawczej w sferę praw człowieka w Konstytucji RP, Kraków 1999, s. 136 n.

${ }^{54}$ Należy podkreślić, że sformułowane uwagi, zwłaszcza wyrażające konieczność „,samoograniczania się" sądu konstytucyjnego w zakresie dokonywanej oceny konstytucyjności kwestionowanych przepisów, nie muszą być adekwatne w sytuacji kontroli ich zgodności z unormowaniami ustawy zasadniczej pozbawionymi pierwiastka ,polityczności”, na przykład statuującymi konkretne prawa podmiotowe jednostki; zob. R. Alexy, Prawa podstawowe w demokratycznym państwie konstytucyjnym, przeł. J. Holocher, [w:] Studia z teorii konstytucyjnego państwa prawa. Konstytucjonalizm, neokonstytucjonalizm, postpozytywizm, red. A. Grabowski, J. Holocher, Kraków 2019, s. 33-52.

55 Przedmiotem kontroli jest więc norma prawna, dekodowana z przepisów wskazanych — jedynie formalnie - w treści wniosku, pytania bądź skargi konstytucyjnej, przy czym cały zabieg dekodowania tej normy zostaje przeprowadzony już przez podmiot inicjujący postępowanie kontrolne przed TK.

$56 \mathrm{Na}$ temat tego i innych rodzajów orzeczeń TK zob. np. M. Florczak-Wątor, Orzeczenia Trybunatu Konstytucyjnego i ich skutki prawne, Poznań 2006, s. 93 n.; P. Tuleja, Wyroki interpretacyjne Trybunału Konstytucyjnego, Poznań 2016, s. 79 n. 
sposób określenia przedmiotu kontroli jest dla podmiotów inicjujących postępowanie jedynie pretekstem do wykorzystania TK jako organu weryfikującego sposób zastosowania danego aktu prawnego w konkretnej, jednostkowej sprawie ${ }^{57}$. Judykat TK ma w ten sposób służyć nie tyle wyeliminowaniu z systemu prawa wadliwych norm prawnych, ile stać się argumentem w dyskursie dotyczącym prawidłowości postępowania organów, które je stosują. Konsekwencją rozstrzygnięcia podjętego przez sąd konstytucyjny (czasem nawet niezależnie od jego treści) jest wówczas często nieuchronne włączenie tego organu w spór stricte polityczny w trzecim ze przywołanych tu ujęć polityczności. Trudno wskazać w tym kontekście w pełni skuteczne, a co najważniejsze - zgodne z obowiązującymi unormowaniami rozwiązanie, które zapobiegłoby tego rodzaju obejściu prawa i instrumentalnemu traktowaniu sądu konstytucyjnego. Wydaje się, że w takich sytuacjach pomocne może być wyjątkowo ścisłe przestrzeganie przez Trybunał wyznaczonych mu przez prawodawcę ram kompetencyjnych i rygorystyczna kwalifikacja treści zarzutów formułowanych przez podmioty inicjujące przed tym organem postępowanie kontrolne. Potrzebna będzie także kwalifikacja, która pozwoli oddzielić argumenty sytuujące się na płaszczyźnie stanowienia prawa od tych związanych wyłącznie ze sposobem zastosowania kwestionowanych przepisów w jednostkowych przypadkach.

\section{ZAKOŃCZENIE}

Za trywialną musi zostać uznana teza potwierdzająca obecność zjawiska polityczności zarówno w sferze tworzenia, jak i stosowania prawa. Może ono dotyczyć zarówno kwestii merytorycznych, jak i proceduralnych. Immanentnie tkwi w treści zasad prawnych i odgrywa znaczenie przy ich kolizji. W dziedzinie prawa konstytucyjnego wynika to przede wszystkim z samego charakteru Konstytucji, która jest jednym z narzędzi uprawiania polityki. Już z tej przyczyny nieporozumieniem byłoby zarzucanie TK aktywizmu w sferze publicznej. Dodatkowym czynnikiem sprzyjającym upolitycznieniu sądu konstytucyjnego jest oczywiście status ustrojowy tego organu. Różny jest wreszcie, ze względu na stopień polityczności, charakter spraw (ze swej natury neutralnych bądź z natury rzeczy politycznych). W całym systemie prawnym istnieją liczne furtki dla polityczności, absurdem byłoby więc abstrahowanie od niej. Nieuniknioność polityczności nie oznacza jednak nieistnienia granic między jej ujęciami. Działalność TK osadzona jest w pierwszym i drugim rozumieniu polityczności, natomiast jego aktywność w sferze kontroli norm nie może przeobrazić się w trzecią z nich.

57 Można tu wskazać także przykłady inicjowania postępowań w sprawie kontroli przepisów, które bynajmniej nie pozostają $\mathrm{w}$ bezpośrednim normatywnym związku $\mathrm{z}$ tego rodzaju jednostkowymi działaniami; zob. wyrok TK z dnia 11 września 2017 roku, sygn. K 10/17, OTK ZU A/2017, poz. 64; oraz glosę do tego orzeczenia autorstwa M. Florczak-Wątor, opublikowaną w Serwisie Informacji Prawnej LEX, nr 328146. 
Określając na wstępie przedmiot i charakter rozważań, stwierdziliśmy, że mają one po części charakter opisowy, a po części postulatywny. W nawiązaniu do tej drugiej jako podsumowanie rozważań pragniemy zaproponować kilka sposobów ograniczenia, a nawet uniknięcia (jeżeli to w ogóle możliwe), nieakceptowalnej ustrojowo polityczności w działalności orzeczniczej TK.

Po pierwsze, TK powinien orzekać ściśle w granicach swej kognicji. W pewnych sytuacjach obejmuje ona także dokonywanie przez sąd konstytucyjny oceny politycznej i kontroli dyskrecjonalności politycznej ustawodawcy (zwłaszcza w przypadku konstytucyjnych norm programowych). Nie powinno to jednak prowadzić do zastępowania oceny politycznej pochodzącej od ustawodawcy własną oceną polityczną sędziów konstytucyjnych ${ }^{58}$. Takie działanie byłoby wyrazem ich niedozwolonego aktywizmu. Orzeczenia, które zostaną wydane z naruszaniem opisywanych wymogów, mogą być uznane za przekroczenie dopuszczalnych granic trybunalskiej polityczności, stanowiąc wyraz instrumentalizacji prawa, a więc dokonywania działań w imię wartości nieakceptowanych w systemie prawa.

Po drugie, TK nie powinien odchodzić bez uzasadnionych racji prawnych od ustabilizowanej linii swoich orzeczeń, przyjętej interpretacji prawa czy utrwalonych poglądów. Tego rodzaju odejścia i modyfikacje stanowiska, oprócz niepożądanego zjawiska polityzacji, mogą stanowić również zagrożenie dla konstytucyjnych mechanizmów samej działalności TK, wśród których istotną rolę odgrywa - statuowana w art. 190 Konstytucji — zasada ostateczności jego orzeczeń. Najogólniej rzecz ujmując, sposobem uniknięcia niepożądanego zarzutu polityczności jest zatem dyscyplina rozumienia pewnych pojęć i konsekwentne oddzielanie przez sam TK jej płaszczyzn. Sąd konstytucyjny nie powinien w związku z tym w swoich judykatach wypowiadać tez arbitralnych, pozbawionych racjonalnego uzasadnienia, niebędących wynikiem rzetelnej, merytorycznej polemiki z wcześniej wyrażanymi stanowiskami i poglądami ${ }^{59}$.

Po trzecie, należy uwzględnić również wpływ sposobu procedowania sądu konstytucyjnego na ocenę zachowania przez ten organ niezbędnego dystansu do sfery polityczności partykularnej. Należy mieć na względzie, że nieusprawiedliwiona okolicznościami (na przykład związanymi z rzeczywistą zawiłością sprawy) opieszałość i przewlekłość postępowania przed TK, której skutkiem jest niewyrażenie merytorycznego stanowiska w kwestii sporu dotyczącego zgodności z Konstytucją kwestionowanych regulacji, może być w istocie odbierana jako opowiedzenie

58 Zob. wyrok Corte Costituzionale z dnia 19 grudnia 1991, sygn. Akt 467/ 1991, http://giurcost.org/decisioni/1991/0467s-91.html, https://obiezionedicoscienza.it/corte-costituzionale-sentenza-19-dicembre-1991-n-467/ (dostęp: 23.05.2020).

59 Negatywnym przykładem może tu być wyrok TK z dnia 16 marca 2017 roku, sygn. Kp 1/17, OTK ZU A/2017, poz. 28; zob. też glosy krytyczne do tego orzeczenia autorstwa M. Florczak-Wątor (Lex 2017) oraz M. Haczkowskiej („Palestra” 2019, nr 9, s. 119-131). 
się przez sąd konstytucyjny po którejś ze stron sporu ${ }^{60}$. Należy bowiem pamiętać, że w typowej dla funkcjonowania TK sytuacji inicjowania kontroli o charakterze następczym przedłużone oczekiwanie na reakcję sądu konstytucyjnego skutkuje tak naprawdę nieustającym obowiązywaniem kwestionowanych norm prawnych.

Na koniec warto zasygnalizować jeszcze jeden problem. Jest nim zagadnienie wpływu modelu kontroli konstytucyjności na zakres i stopień polityczności. Sprowadza się ono do odpowiedzi na pytanie, który z modeli, a mianowicie model kontroli konstytucyjności dokonywanej przez TK czy też model kontroli rozproszonej (zdekoncentrowanej) ${ }^{61}$, w większym stopniu służy apolityczności. Nie przesadzając w tym miejscu rozstrzygnięcia tego dylematu, trzeba zauważyć, że także drugi ze wspomnianych modeli kontroli prawa nie chroni całkowicie przed zagrożeniami związanymi z przekraczaniem granic między omawianymi tu przejawami polityczności. Dotyczy to zwłaszcza interpretacji tych norm konstytucyjnych, które wprost odwołują się do problemu prowadzenia przez władze publiczne wskazanej przez ustrojodawcę polityki bądź też operują przesłankami wymagającymi do ich interpretacji odwołania do rozmaitych kryteriów i ocen pozaprawnych (na przykład art. 31 ust. 3 Konstytucji $)^{62}$. Ich stosowanie, zwłaszcza jako podstawy kontroli innych (niższych hierarchicznie) norm prawnych, nierozłącznie niesie z sobą niebezpieczeństwo wejścia przez organ jej dokonujący w sferę polityczności partykularnej. Problem tkwi bowiem nie tyle w tym, kto normy te stosuje, ile raczej w samym fakcie ich zastosowania jako wzorca kontroli. Tym samym część analizowanych tu niebezpieczeństw towarzyszących działalności TK stałaby się udziałem również sądów powszechnych, administracyjnych czy też Sądu Najwyższego.

\section{THE POLITICAL OF THE CONSTITUTIONAL REVIEW OF NORMATIVE ACTS IN THE POLISH LEGAL SYSTEM - SELECTED PROBLEMS}

Summary

The first part of the paper is devoted to the analysis of the concept of politicalness. Its purpose is to distinguish different meanings of politicalness, along with their reference to the activities of the

60 Przykładowo takie wątpliwości wywołuje w ostatnim okresie zwłaszcza zwłoka w podjęciu rozstrzygnięcia w sprawie emerytur i rent byłych funkcjonariuszy pełniących służbę na rzecz totalitarnego państwa (sygn. P 4/18); zob. https://ipo.trybunal.gov.pl/ipo/Sprawa?cid=2\&sprawa=20215 (dostęp: 4.09.2020).

61 Zob. np. M. Gutowski, P. Kardas, Sądowa kontrola konstytucyjności prawa. Kilka uwag o kompetencjach sądów powszechnych do bezpośredniego stosowania konstytucji, „Palestra” 2016, nr 4, s. 5-30.

62 Akceptując pogląd o dopuszczalności przeprowadzania przez sądy incydentalnej (rozproszonej) kontroli konstytucyjności aktów prawnych (zwłaszcza ustaw), nie można wykluczyć uwzględniania także tych norm jako podstawy takiej kontroli. 
Polish Constitutional Tribunal in the sphere of constitutional review. The second part of the study concerns the factors determining the Constitutional Tribunal's entering into the prohibited sphere of politicalness, and consequently the politicization of its functioning. These factors are related to both constitutional control standards of the law and its subject matter. The authors also attempted to indicate the material and procedural elements of the activities of the constitutional court that may serve to protect the unpolitical nature of this judicial authority.

Keywords: the political, limited politics, particular politics, constitutional review, program norms, Constitutional Tribunal

\section{BIBLIOGRAFIA}

Alexy R., Prawa podstawowe w demokratycznym państwie konstytucyjnym, przeł. J. Holocher, [w:] Studia z teorii konstytucyjnego państwa prawa. Konstytucjonalizm, neokonstytucjonalizm, postpozytywizm, red. A. Grabowski, J. Holocher, Kraków 2019.

Alexy R., Theorie der Grundrechte, Baden-Baden 1985.

Araszkiewicz M., Gizbert-Studnicki T., Teoria praw podstawowych Roberta Alexy'ego, „Przegląd Sejmowy" 2011, nr 3.

Arystoteles, Polityka, przeł. L. Piotrowicz, Warszawa 2002.

Biernat T., Między polityka a prawem. Problem ,, upolitycznienia” tworzenia prawa, [w:] Polityczność nauki prawa i praktyki prawniczej, red. A. Bator, P. Kaczmarek, „Przegląd Prawa i Administracji” 110, 2017.

Błaszczykiewicz L., Polityczność w teoriach socjologicznych Parsonsa, Giddensa i Bourdieu, [w:] Polityka i polityczność. Problemy teoretyczne i metodologiczne, red. A. Czajowski, L. Sobkowiak, Wrocław 2012.

Dahl R.A., Modern Political Analysis, Prentice Hall 1991.

Florczak-Wątor M., Glosa do wyroku TK z 11.09.2017, K 10/17, OTK ZU A/2017, poz. 64, LEX nr 328146.

Florczak-Wątor M., Glosa do wyroku TK z 16.03.2017, Kp 1/17, OTK ZU A/2017, poz. 28, LEX 2017.

Florczak-Wątor M., Orzeczenia Trybunału Konstytucyjnego i ich skutki prawne, Poznań 2006.

Florczak-Wątor M., Ważenie zasad konstytucyjnych jako podstawa sądowej wykladni prawa, [w:] Argumentacja konstytucyjna w orzecznictwie sądowym, red. A. Kotowski, E. Maniewska, Warszawa 2016.

Garlicki L., Artykut 76, [w:] Konstytucja RP. Komentarz, red. L. Garlicki, t. 5, Warszawa 2007.

Gizbert-Studnicki T., Grabowski A., Normy programowe w Konstytucji, [w:] Charakter i struktura norm konstytucji, red. J. Trzciński, Warszawa 1997.

Gutowski M., Kardas P., Sądowa kontrola konstytucyjności prawa. Kilka uwag o kompetencjach sąów powszechnych do bezpośredniego stosowania konstytucji, „Palestra” 2016, nr 4.

Haczkowska M., Glosa do wyroku TK z 16.03.2017, Kp 1/17, OTK ZU A/2017, poz. 28, „Palestra 2019", nr 9 .

Jabłoński A., Polityka. Teoretyczna ewolucja pojęcia, [w:] Polityka i polityczność. Problemy teoretyczne i metodologiczne, red. A. Czajowski, L. Sobkowiak, Wrocław 2012.

Konstytucja Rzeczypospolitej Polskiej. Komentarz, red. P. Tuleja, Warszawa 2019.

Kordela M., Aksjologiczna wykładnia prawa, [w:] Polityczność nauki prawa i praktyki prawniczej, red. A. Bator, P. Kaczmarek, „Przegląd Prawa i Administracji” 110, 2017.

Maroń G., Formuła ważenia zasad prawa jako mechanizm usuwania ich kolizji na przykładzie koncepcji Roberta Alexego, „Zeszyty Naukowe Uniwersytetu Rzeszowskiego. Seria Prawnicza” 53, 2009. 
Mikłaszewicz K., Objaśnienie do art. 75, [w:] Konstytucja RP. Komentarz, t. 1, red. M. Safjan, L. Bosek, Warszawa 2016.

Morawski K., Laclana i Mouffe teoria polityczności, [w:] Polityka i polityczność. Problemy teoretyczne i metodologiczne, red. A. Czajowski, L. Sobkowiak, Wrocław 2012.

Morawski L., Spór o pojęcie państwa prawnego, „Państwo i Prawo” 1994, nr 4.

Opałek K., Zagadnienia teorii prawa i teorii polityki, Warszawa 1986.

Polityka/polityczność. Granice dyskursu, red. B. Krzysztan, W. Ufel, M. Zieliński, Wrocław 2016.

Radziewicz P., Tuleja P., Konstytucyjny spór o granice zmian organizacji i zasad działania Trybunatu Konstytucyjnego; czerwiec 2015-marzec 2016, Warszawa 2017.

Schmitt C., Teologia polityczna i inne pisma, przeł. M.A. Cichocki, Kraków 2000.

Sulikowski A., Konstytucjonalizm wobec „zemsty postmodernizmu”, [w:] Polityczność nauki prawa i praktyki prawniczej, red. A. Bator, P. Kaczmarek, „Przegląd Prawa i Administracji” 110, 2017.

Tuleja P., Stosowanie Konstytucji RP w świetle zasady jej nadrzędności (wybrane problemy), Kraków 2003.

Tuleja P., Wyroki interpretacyjne Trybunału Konstytucyjnego, Poznań 2016.

Weber M., Gospodarka i społeczeństwo. Zarys socjologii rozumiejacej, Warszawa 2002.

Wojtyczek K., Granice ingerencji ustawodawczej w sfere praw czlowieka w Konstytucji RP, Kraków 1999.

Wronkowska S., Kilka tez o instrumentalizacji prawa i ochronie przed nią, [w:] Polityczność nauki prawa i praktyki prawniczej, red. A. Bator, P. Kaczmarek, „Przegląd Prawa i Administracji” 110, 2017.

Zajadło J., Prawoznawstwo - polityczność nauki czy nauka polityczności?, [w:] Polityczność nauki prawa i praktyki prawniczej, red. A. Bator, P. Kaczmarek, „Przegląd Prawa i Administracji” 110, 2017. 